\title{
Jogpolitika
}

\author{
TÓTH ANDRÁS*
}

\section{A közértéket teremtő prevenció magasabb foka a versenyjogban}

\author{
Higher Level Prevention as Public Value in Competition Law
}

\begin{abstract}
ABSZTRAKT
A szociális szabályozás területén Sparrow által kidolgozott problémamegoldó mechanizmus a versenyjogba is átültethető a károk megelőzése érdekében. A versenyhatóságok (mint védelmi jellegü állami szervek) célja is a közérték-teremtés kell, hogy legyen. Ennek sikere a hatóságok arra való képességében rejlik, hogy mennyire tudják a valós társadalmi problémákat megragadni, azokat megelőzni, illetve hatékonyan felszámolni. A versenyhatóságok a közértéket úgy teremtik, ha biztosítják a versengő piaci környezetet a piaci erő visszaszoritásával, a belépési akadályok felszámolásával. A megelözés fokozása különösen fontos, amikor a piacok koncentrálódása tendenciaként jelentkezik a világgazdaságban. Annak érdekében, hogy a maximális preventív hatás a versenyjogban elérhető legyen, minden megelözésre szolgáló eszközt hatékonyan kell müködtetni. Ez magában foglalja a strukturális kötelezések alkalmazását, illetve az ex-ante szabályozásra való átváltást, amikor az ex-post intézkedések hatástalannak bizonyulnak.
\end{abstract}

Kulcsszavak: koncentráció, elrettentés, leválasztás, ex-ante szabályozás, prevenció

\section{ABSTRACT}

The problem-solving mechanism developed by Sparrow in the field of social regulation could also be implemented in competition law in order to prevent the recurrence of competition problems in a given industry. Competition authorities' (like protection-type agencies) aim is the creation of public value. This is measured in terms of their ability to solve social problems by preventing or controlling harms. In the case of competition authorities, the public value is achieved by ensuring a competitive market environment through the curtailment of market power and the removal of barriers to entry. The public value of prevention is especially important when markets tend to become concentrated. In order to achieve the maximum preventive effect, all prevention tools must be operated effectively. This includes imposing structural remedies or switching to ex-ante prevention (regulation) when ex-post enforcement proves ineffective.

Keywords: concentration, deterrence, divestitures, ex-ante regulation, prevention

* Dr. Tóth András tanszékvezető egyetemi docens, Károli Gáspár Református Egyetem Állam- és Jogtudomá- 
Az állami szervek tevékenységét Moore két nagy kategóriába sorolja: (1) szolgáltatásnyújtás (igazolványok kiálítása, nyilvántartásba vételek, engedélyek kiadása, szociális támogatások stb.); valamint (2) védelem (rendvédelem, biztonság, környezetvédelem, fogyasztóvédelem stb.). Mindkét feladat közérték-teremtés. ${ }^{1}$ Míg a magánszférában a sikert profitban mérik, addig a közszférában a mérce a közérték-teremtés. A közszolgáltatást nyújtó szervek esetében a közérték-teremtés a fogyasztók elégedettségében mérhető, míg a védelmi típusú szervek (mint amilyenek a versenyhatóságok) esetében azok arra való képességében, hogy miként tudnak hatékonyan megoldani társadalmi problémákat, károk megelőzése vagy felszámolása révén. Nem véletlen, hogy a versenyhatóságok többsége is „konzekvencionalistaként" tekint magára, ${ }^{2}$ vagyis elsődleges céljuk, hogy az elrettentés révén prevenciót (kármegelőzést) érjenek el. ${ }^{3}$ Míg a kár megelőzése kétségkívül társadalmilag hasznosabb és értékesebb, mint a kár bekövetkezését követően annak kezelése és felszámolása, ugyanakkor nem észszerű annak feltételezése, hogy minden jövőbeli potenciális kár elkerülhető megelőző intézkedésekkel. Emiatt a védelmi típusú állami szerveknek a megelőzés mellett a károk felszámolását ugyanúgy fókuszban kell tartaniuk.

A kármegelözés akkor teremt közértéket, ha stratégiailag átgondoltan müködik, miáltal felszámolásra kerülnek a károsodáshoz, illetve azok ismétlődéséhez vezető okok. Sparrow a szociális szabályozás (azaz, például az egészségügy, biztonság, jólét, munkafeltételek és környezet területén érvényesülő szabályok) kapcsán mutatott rá erre, amikor az állami szervek működésének középpontjába a valós problémák megragadását, felszámolását, és ezáltal a károsodás jövőbeli bekövetkezésének elkerülését tette. ${ }^{4}$ (Például az autóbalesetek számának csökkentése, ami nem feltétlenül merül ki a gyorshajtás szankcionálásában). Ebben a tekintetben a megfelelő prevenció egy adott probléma megismétlődésének megakadályozását jelenti a károsodásra vezető okok azonosítása és kezelése által.

A piaci versenynek makrogazdasági hatásai vannak. ${ }^{5}$ Ebben a tekintetben a versenyhatóságok munkája hozzájárul az általános gazdasági fejlődéshez. Az EU-ban a verseny védelméhez kapcsolódó feladatokat jellemzően állami szervek végzik. A versenyhatóságok védelmi típusú hatóságként a közértéket úgy teremtik meg, ha biztosítják a rendelkezésükre álló eszközökkel a versengő piaci környezetet a piaci hatalom korlátozásával és a belépési akadályok elhárításával.

Jelen tanulmányban a vonatkozó magyar és külföldi szakirodalom áttekintésével, valamint jogesetek feldolgozásával azt mutatom be, hogy ezt a szociális szabályozás

\footnotetext{
${ }^{1}$ Moore, Mark H.: Creating Public Value, Strategic Management in Government. Harvard University Press, Cambridge, Massachusetts, 1995.

${ }^{2}$ HuIzING, Pieter J. F.: Proportionality of Fines in the Context of Global Cartel Enforcement. World Competition Law and Economic Review, 2020/1, 61-86.

${ }^{3}$ Setting of Fines for Cartels in ICN Jurisdictions. Report to the $7^{\text {th }}$ ICN Annual. International Competition Network, Kyoto, April 2008, 44.

${ }^{4}$ SpARrow, Malcolm K.: The Regulatory Craft, Controlling Risks, Solving Problems, and Managing Compliance. Council for Excellence in Government. Brookings Institution Press, Washington, D.C., 2000.

${ }^{5}$ BAKER, Jonathan B.: The Antitrust Paradigm: Restoring a Competitive Economy. Harvard University Press, Cambridge, Massachusetts, 2019.
} 
területére kidolgozott problémamegoldó mechanizmust miként lehet átültetni a gazdasági szabályozás területére egy adott iparágban felmerülő versenyt érintő problémák megismétlődésének megelőzése érdekében. Amellett érvelek, hogy a károk megelőzését kell a versenyhatóságok müködésének középpontjába állítani. Ez azt jelenti, hogy minden rendelkezésükre álló eszközt hatékonyan kell működtetniük a maximális prevenciós hatás érdekében. Ez magában foglalja az ex-ante szabályozásra való átváltást is, amikor az ex-post intézkedések hatástalannak bizonyulnak.

Annak bemutatása előtt, hogy miként ültetethető át a versenyjogba a szociális szabályozás tekintetében kifejlesztett problémamegoldó mechanizmus, a 2. fejezetben bemutatom a piaci hatalmat, mint a versenyre leginkább káros tényezőt, amelynek a megelőzés fókuszába kell kerülnie. A 3. fejezetben bemutatom, hogyan működnek a megelőző eszközök a versenyjogban és milyen korlátai vannak. A 4. fejezetben azt tárgyalom, hogy a versenyhatóságoknak teljes körűen és következetesen ki kell használniuk a rendelkezésükre álló megelőző eszközöket annak érdekében, hogy be tudják tölteni a védelmi szerepüket és megóvják a társadalmat a károk bekövetkeztétől a valódi közérték előállítása érdekében. Ez szükségszerűen nem csak bírságok, hanem ex-ante szabályozási kezdeményezések, valamint ahol helyénvaló, strukturális beavatkozások (például vállalati feldarabolások) következetes alkalmazását is jelentheti.

\section{A piaci hatalom, mint a verseny szempontjából legnagyobb kár}

A verseny az allokációs hatékonyság javulásához vezet azáltal, hogy a piaci szereplőket arra ösztönzi, hogy azok a lehető leghatékonyabb szinten müködjenek. Ez a hatékonyág (X-hatékonyság) biztosítja azt, hogy a piacgazdaságnak ne legyen több vesztese, mint amennyi annak működéséből természetszerüleg fakad. Hiába

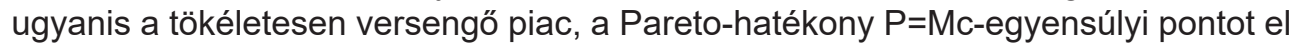
nem érő jövedelmi szinttel rendelkező fogyasztók ennél a legkedvezőbb kimenetnél sem férnek hozzá a jószághoz. Ezt a piacgazdaság müködésének természetéből fakadó igazságtalanságot a verseny torzítottsága (a piaci hatalom) csak tovább súlyosítja. Egyrészről károsan hat az erőforrások allokációjára, amely alapvető rendeltetése a gazdaságnak, ugyanis még több fogyasztó szorul ki a jószág élvezetéből, mint tökéletesen versengő kimenet esetén. A gazdaság alapvető funkciója, hogy lehetővé tegye a fogyasztók számára a szükségleteik kielégítését. Amennyiben a verseny korlátozódik, úgy a termelés csökken és az erőforrások allokációja (a gazdaság fö funkciója) kárt szenved, mert kevesebb fogyasztó jut hozzá az igényeit kielégítő javakhoz, mint a korlátoktól mentes versenyben. Másrészt alapvető fogyasztási termékek esetén ennek az allokációs hatékonyságnak a vesztesége többlet terhet rak az adófizetőkre, ugyanis az államnak nem csak a piacgazdaság alapértelmezett tökéletlen működéséből fakadóan sérelmet szenvedett állampolgárokról kell gondoskodnia, hanem azokról is, akiknek amúgy lett volna jövedelme a versengő és nem versengő kimenet között, de a verseny korlátai miatt ők is kiszorulnak.

A piaci hatalom károsságát mi sem bizonyítja jobban, minthogy a piacok elmúlt időszakban tapasztalt koncentrációja az USA-ban reflexióra késztetett a versenypo- 
litika alapjait és valódi célját illetően (különösen a piaci koncentrációt eredményező fúziók kapcsán). ${ }^{6} \mathrm{~A}$ technológiai óriások ráadásul mindenki szeme láttára emelkedtek fel, és a hétköznapi emberek számára is sokkal kézzel foghatóbb problémákat okoznak. (Az USA-ban négy felhasználóból hárman aggódnak a legnagyobb technológiai platformok által birtokolt piaci erő miatt. ${ }^{7}$ ) Mára a Google dominálja a keresőmotorok piacát, ${ }^{8}$ a mobiltelefon operációs rendszer piacot, ${ }^{9}$ és a Facebook pedig meghatározó a közösségi média területén. ${ }^{10}$

Különösen a digitális piacok kapcsán merült fel ${ }^{11}$ (bár vannak, akik ezt vitatják) ${ }^{12}$ hogy a piacok koncentrálódása arra vezethető vissza, hogy az amerikai versenyjog az 1970-es években letért a szociális vagy strukturalista megközelítés útjáról, amelyet felváltott az árközpontú megközelítés a Chicagói iskola hatására a fogyasztói jólét jegyében. Felerősödtek azok a hangok, amelyek szerint ezért vissza kell térni az amerikai versenyjog eredeti megközelítéséhez. Ezt az irányzatot nevezik neostrukturalistának, neo-Brandeis iskolának, vagy hívják antitröszt populizmusnak, illetve hipszter antitrösztnek is. Az amerikai versenyjog korai szakaszában, a 20. században (egészen a század közepéig) a piaci koncentrációra a nem hatékony müködés egyik forrásaként tekintettek. Louis Brandeis szerint a piaci folyamatok természetes eredményével szembe lehet szegülni, ha az koncentrációhoz vezet. Robert Bork volt az, aki a fogyasztói jólétet helyezte a trösztellenes politika középpontjába és az alacsony árat tette meg egyedüli fokmérőjének. ${ }^{13}$ Bork szerint a magas piaci részesedés nagy valószínüséggel betudható a méretgazdaságosságnak és a nagyobb hatékonyságnak. Meglátása szerint a trösztellenes szabályozás csak azt szolgálja, hogy a kisvállalkozásokat megvédje a versenytől, szétaprózza a piacokat, és csökkentse a költség-hatékonyságot. Amikor a Chicagói iskola domináns lett, az lett a széles körben elfogadott nézet, hogy belépési (szabályozó) korlátok hiányában az erőfölényes helyzet úgysem fenntartható hosszútávon. Mára azonban

${ }^{6}$ BAKer: i. m.; Tepper Jonathan-HeARn Denise: The Myth of Capitalism, Monopolies and the Death of Competition. Wiley, Newark, 2019.; KHAN, Lina M.: Amazon's Antitrust Paradox. The Yale Law Journal, 2017/3, 564-907.

${ }^{7}$ Raymond, Chris: Americans Say Nation's Big Tech Companies Have Too Much Power. Consumer Reports, September 24, 2020. https://www.consumerreports.org/consumer-protection/big-tech-companies-have-toomuch-power-americans-say/ (2021. 06. 10.).

${ }^{8}$ Johnson, Joseph: Global Market Share of Search Engines 2010-2020. Statista, Nov 20, 2020. https://www. statista.com/statistics/216573/worldwide-market-share-of-search-engines/ (2021. 03. 15.).

${ }^{9}$ O'Dea, S.: Market share of mobile operating systems worldwide 2012-2020. Statista, Nov 30, 2020. https:// www.statista.com/statistics/272698/global-market-share-held-by-mobile-operating-systems-since-2009/ (2021. 03. 15.).

${ }^{10}$ Nestor, Gilbert: Essential Facebook Statistics: 2020 Market Share Analysis \& Data. Finances Online, 2021, https://financesonline.com/facebook-statistics/ (2021. 03. 15.)

${ }^{11}$ GöNCZÖL Tünde: A hipszter antitrösztirányzat és kritikusai. In: Valentiny Pál-Nagy Csongor István-Berezvai Zombor (szerk.): Verseny és Szabályozás 2018. MTA KRTK Közgazdaság-tudományi Intézet, Budapest, 2019, 13-44.

${ }^{12}$ WRIGHT, Joshua D.-DoRSEY, Elyse-KLICK, Jonathan-RYBNICEK, Jan M.: Requiem for a Paradox: The Dubious Rise and Inevitable Fall of Hipster Antitrust. Arizona State Law Journal, George Mason Law and Economics Research Paper, 2018, No. 18-29.

13 Tepper-Hearn: i. m., 157. 
a gyakorlat a Chicagói iskolát meghaladta abban az értelemben, hogy a fogyasztói jóléti hatáselemzés jelenleg már nem kizárólag árközpontú. ${ }^{14}$

Mindenesetre ezen a példán is jól látszik, hogy a piaci hatalom a versenyjogban kritikus kérdés, olyannyira, hogy annak elharapózása esetén egyenesen az alapjai is megkérdőjeleződhetnek miatta. Kovacic szerint csak idő kérdése volt, hogy az üzleti botrányok vagy a gazdasági válságok következtében felszínre törjenek a populista érzelmek a nagyvállalatokkal szemben, és a politikának arra kell majd irányítania a figyelmét, hogy szigorúbb mércét állítson a versenyellenes magatartások értékelése vonatkozásában, amely végül dekoncentrációhoz fog vezetni.

Az Európai Unió versenyjogáról el lehet mondani, hogy eleve „hipszter” abban az értelemben, hogy az EU versenyjogát meghatározó német ordo-liberális iskola a II. világháború keserü tapasztalatain okulva összekötötte a piaci hatalom ellenszerét a versenyt, a demokrácia megőrzésével. ${ }^{15}$ Erre is visszavezethetően az EU-ban az erőfölényes vállalatok többletfelelősségi elve ${ }^{16}$ már eddig lehetővé tette az Európai Bizottság számára a fellépést a digitális óriások ellen. ${ }^{17} \mathrm{Az}$ EU-ban így az amerikaihoz hasonló módon nem kérdőjeleződött meg a versenyjog hatályos érvényesülési koncepciója. Viszont a digitális piacokon létrejött piaci hatalmak az EU-ban is felvetették az erőteljesebb versenyjogi beavatkozást (feldarabolás alkalmazását) ${ }^{18}$ vagy a versenyjogot meghaladó szabályozás szükségességét. ${ }^{19}$

\section{Megelőzés a versenyjogban}

A közértéket jelentő prevenció tehát különösen fontos, amikor a piacok koncentrálódnak, ${ }^{20}$ vagy legalábbis annak érzete még a versenyjog alapjait is kérdésessé

${ }^{14}$ Hovenkamp, Herbert J.: Is Antitrust's Consumer Welfare Principle Imperiled? Penn Law: Legal Scholarly Repository, University of Pennsylvania Carey Law School, 2019. https://scholarship.law.upenn.edu/cgi/viewcontent.cgi?article=2987\&context=faculty_scholarship (2021. 03. 15.).

${ }^{15}$ DeUtscher, Elias-MAKRIS, Stavros: Exploring the Ordoliberal Paradigm: The Competition-Democracy Nexus. Competition Law Review, 2016/2, 181-214.; Gerber, David J.: Constitutionalizing the Economy: German Neo-liberalism, Competition Law and the "New" Europe. The American Journal of Comparative Law, 1994/1, 25-84.

16 322/81. sz. NV Nederlandsche Banden Industrie Michelin kontra az Európai Közösségek Bizottsága ügyben 1983. november 9-én hozott ítélet (ECLI:EU:C:1983:313).

17 VALDIVIA, Eduardo Aguilera: The Scope of the Special Responsibility upon Vertically Integrated Dominant Firms after the Google Shopping Case: Is There a Duty to Treat Rivals Equally and Refrain from Favouring Own. World Competition, 2018/1, 43-68; SAUTER, Wolf: A Duty of Care to Prevent Online Exploitation of Consumers? Digital Dominance and Special Responsibility in EU Competition Law. Journal of Antitrust Enforcement, 2020/2, 406-427.

${ }^{18}$ Robertson, Adi: European Lawmakers Asked Mark Zuckerberg Why They Shouldn't Break up Facebook. The Verge, May 22, 2018. https://www.theverge.com/2018/5/22/17380982/mark-zuckerberg-europeanparliament-meeting-monopoly-antitrust-breakup-question (2021. 03. 15.).

${ }_{19}$ Furman, Jason-Coyle, Diane-Fletcher, Amelia-McAuley, Derek-Marsden, Philip: Unlocking Digital Competition. Report of the Digital Competition Expert Panel, 2019, 84. https://assets.publishing.service.gov.uk/ government/uploads/system/uploads/attachment_data/file/785547/unlocking_digital_competition_furman_ review_web.pdf (2021. 03. 15.).

20 Stiglitz, Joseph: The New Era of Monopoly is Here. The Guardian, 13 May 2016. https://www.theguardian. com/business/2016/may/13/-new-era-monopoly-joseph-stiglitz (2021. 03. 15.). 
teszi. Jelen tanulmányban azonban nem a versenypolitika meggyengülésének okait vizsgálom, s azzal sem foglalkozom, hogy miként lehetne szigorítani a versenyjogi anyagi jog érvényesítését. Inkább arra mutatok rá, hogy a versenyjogi ex-post elrettentés milyen más eszközökkel kiegészítve tudna hozzájárulni ahhoz, hogy a versenyjog a társadalmilag nagyobb közértéket jelentő magasabb szintű prevenciós szintet érje el. Álláspontom szerint ugyanis ez önmagában - az amúgy is hatásalapú elemzések nehézségei miatt kétes eredményekkel kecsegtető - versenyjogi anyagi jogi beavatkozások szigorításával nem is volna lehetséges. A prevenció magasabb szintjének eléréséhez szükséges lépések előtt azonban bemutatom a versenyjogi prevenció müködési mechanizmusát.

A versenyhatóságoknak szabályozási és nem szabályozási eszközök állnak rendelkezésére a gazdaság teljesítményének javítását célzó feladataik elvégzésére. Ennek érdekében a törvényhozó felruházta a versenyhatóságokat ex-post és exante (összefonódás ellenőrzése) szabályozói eszközökkel. A nem szabályozási eszközök közé tartozik a jogalkotási folyamatban való részvétel a versengő környezet előmozdítása érdekében (versenypártolás). A versenyhatóságok ilyen jogalkotási javaslatainak azonban az alábbiak szerint szintén lehetnek preventív hatásai, sőt ezek jelentik a prevenció rejtett tartalékait.

\subsection{Az ex-ante szabályozás és az ex-post beavatkozás prevenciós hatása}

Az ex-ante szabályozás a jövőbeli károk megelőzését célozza, és szemben az ex-post beavatkozással, nem múltbeli magatartás adja alkalmazásának kiindulópontját. Az ex-ante szabályozás kétféleképpen rendelkezik megelőző hatással: az előzetes engedélyezés (például az összefonódás ellenőrzése esetében), valamint jövőre vonatkozó konkrét magatartási szabályok meghatározása formájában. Ez utóbbi kiindulópontja nem valamilyen múltbeli piaci magatartás, hanem bizonyos fokú piaci erőtől jövőre nézve konkrétan elvárt magatartási szabály (lásd például a jelentős piaci erőn alapuló telekommunikációs szabályozást, vagy az Európai Bizottság által 2020-ban előterjesztett, digitális piacokról szóló jogszabály-javaslat kötelezettségeit, amelyekre alább még visszatérek), amelynek célja a piaci hatalom ellensúlyozása. Előzetes engedélyezés alkalmazására akkor van mód, ha a jövőbeli, elkerülendő potenciális kockázat valamilyen kézzelfogható fizikai eszköz (például vakcina, épület kivitelezés) megvalósításából vagy intézményi lépésekből (például összefonódás) fakad.

Az ex-post beavatkozás megelőző hatása a múltban történt meghatározott piaci magatartások kapcsán nagy valószínüséggel bekövetkező beavatkozás, szankció révén jelentkezik. Az ex-post beavatkozás során magatartásbeli és strukturális korrekciók is alkalmazhatók a jövőre nézve, ugyanakkor ez esetben - szemben az exante szabályozással - mindig van egy múltbeli piaci magatartás, amely a szabályozói beavatkozás alapjául szolgál. Két iskolát különböztethetünk meg a bírság célja vonatkozásában. Az első a megtorlást tekinti a büntetés végső céljának, a második (Jeremy Bentham filozófiájával összhangban) a jövőbeli bủnelkövetés megelőzésére összpontosít az elrettentés révén (konzekvencionalista iskola). ${ }^{21}$ 
A prevenció specifikus és generális is egyben, hiszen a beavatkozás egyfelől a jogérvényesítési intézkedéssel érintett konkrét piaci szereplő jövőbeli jogsértésektől való elrettentésére irányul (közvetlen prevenció), másfelől tágabb körben olyan üzenetet közvetít a piac felé, amely általában irányul a jövőbeli káros piaci magatartás tanúsításától való visszatartásra (közvetett prevenció). A generális prevenció szélesebb körü érvényesülése okán több kárt tud megelőzni. ${ }^{22}$ Ugyanakkor a speciális prevenció nélkül ez a generális preventív hatás nem ölthetne testet. A specifikus és generális prevenció ezen egymást kiegészítő működése alapvető jelentőségű az ex-post beavatkozás prevenciós hatása szempontjából. Az ex-ante szabályozás erőteljesebb preventív hatással bír abból fakadóan, hogy a piaci szereplők számára előre világos az elvárt magatartás. Az ex-post prevenció viszont csak egy olyan megelőzési mechanizmust biztosít, amely a generális és a specifikus prevenció egymást kiegészítő müködésén alapszik, amit összességében így elrettentésen alapuló prevencióként is ismerünk. Ugyanakkor meg kell jegyezni, hogy az ex-ante szabályozásnak is van elrettentő hatása (lásd például: összefonódások ellenőrzésére vonatkozó tilalmak vagy beavatkozások, amelyek hatással lehetnek a jövőbeli potenciális összefonódásokra). ${ }^{23}$

\subsection{A társadalmi félelem szerepe a prevencióban}

A szabályozás általi prevenciót a kockázat (a károsodás) bekövetkezésétől való társadalmi félelem motiválja. A károsodás szabályozás általi megelőzése azt tűzi ki célul, hogy észszerű intézkedések révén a kár bekövetkeztének kockázatát egy társadalmilag még elfogadható szintre csökkentse, mert egyébként lehetetlen teljes körű garanciát biztosítani az összes potenciális jövőbeli kár megelőzésére. A társadalmilag elfogadható kockázat szintje nem feltétlenül objektív tényeken alapszik. A kockázat társadalmi megítélése és a félelem szoros összefüggést mutat a kockázat észlelhetőségével. Így például bár egy nukleáris katasztrófa vagy repülőgépszerencsétlenség bekövetkeztére gyakorlatilag sokkal kisebb az esély, az emberek sokkal inkább tartanak tőle, mint egy autóbalesettől, annak ellenére, hogy ez utóbbi sokkal gyakrabban következik be. Ha az emberek könnyedén és élénken fel tudnak idézni releváns példákat, jóval nagyobb eséllyel fognak rettegni és aggódni, mint amikor a kockázat nem olyan élénken elképzelhető. ${ }^{24}$ Mindez kihat a szabályozás alakítására is, miként a döntéselmélet rámutatott, hiszen a kormányok hajlamosak az erőforrásaikat az emberek félelmeinek megfelelően allokálni. ${ }^{25}$

Könnyebben észlelhető károk esetén tehát nagyobb társadalmi igény van a megelőzésre. Ahogyan fent bemutattam, az ex-ante szabályozás nagyobb biztonságot jelent a kármegelőzés tekintetében, mint az ex-post beavatkozás, ugyanakkor nem

\footnotetext{
22 Davies, Stephen-Mariuzzo, Franco-Ormosi, Peter L.: Quantifying the Deterrent Effect of Anticartel Enforcement. Economic Enquiry, 2018/4. (https://doi.org/10.1111/ecin.12574)

${ }^{23}$ Seldeslachts, Jo-Clougherty, Joseph A.-Barros, Pedro P.: Remedy for Now but Prohibit for Tomorrow: The Deterrence Effects of Merger Policy Tools. WZB, Markets and Political Economy Working Paper, February 2007., No. SPII 2007-02. (http://dx.doi.org/10.2139/ssrn.1009135)

24 ThaleR, Richard H.-SunsteIn Cass R.: Nudge, Improving Decisions About Health, Wealth, and Happiness. Yale University Press, New Haven \& London, 2009, 25.

25 Thaler-Sunstein: i. m., 26.
} 
minden kárt lehet megelőzni ex-ante eszközök alkalmazásával sem (lásd az ipari katasztrófák megelőzésére elfogadott Seveso rezsimet $\left.{ }^{26}\right)$. Emiatt a jelentős társadalmi félelmekkel járó kockázatok esetén elsősorban meg kell próbálni ex-ante preventív szabályozási eszközöket kialakítani (például a repülésbiztonság, a gyógyszer $\mathrm{K}+\mathrm{F}$, az ipari vagy nukleáris létesítmények esetén). Ettől még az ex-ante szabályozási eszközök megfigyelhetők olyan absztrakt károk megelözése kapcsán is, mint a piaci hatalmat megelőző összefonódás kontroll a versenyjogban, amikor a társadalmi félelem nem olyan jelentős.

Ráadásul azzal is szembe kell nézni, hogy nem minden társadalmi félelem oszlatható el ex-ante eszközök használatával. Az ex-ante szabályozás alkalmazásának feltételei nem állnak fenn, ha lényegében emberi tényezőkre vagy emberi magatartásra vezethető vissza a kockázat. Ez esetben maga a szabályozás keltette félelem (az ex-post beavatkozással járó fenyegetés) az egyetlen lehetséges eszköze a prevenciónak. Ahogyan a társadalmi félelem preventív szabályozáshoz vezethet, úgy a szabályozás emberi tényezőre visszavezethető kockázatok esetén maga használja a félelmet eszközeként a károsodás megelözésére. Ebben az esetben az egyetlen rendelkezésre álló eszköz arra, hogy kiküszöböljük az alapvetően emberi magatartásban, tényezőkben rejlő kockázatokat, a specifikus és generális prevenció közötti egymást kiegészítő kapcsolat hatékonyságán nyugvó (elrettentésként ismert) ex-post megelőzés.

\subsection{Az elrettentés, mint az ex-post beavatkozás prevenciós hatása}

Ahogyan említettem, az ex-post szabályozás megelőző hatása a speciális és generális prevenció egymást kiegészítő működésének sikerén múlik, melynek kulcsa a kockázat (jelen esetben a szabályozói beavatkozás) érzékelhetősége. Az ex-post beavatkozás prevenciós hatása esetében a fenyegetés magából a szabályozói beavatkozásból ered (bírság, magatartási vagy strukturális korrekció) illetve a jogsértés esetén a beavatkozás nagy valószínúséggel való bekövetkeztétöl. Minél inkább elhiszik ugyanis a norma címzettjei, hogy a normaszegésük nem marad büntetlen, annál nagyobb a normakövetési hajlandóság. Mindez pedig szoros összefüggést mutat a szabályozói beavatkozás érzékelhetőségével. Gal szerint a preventív elrettentő hatást így, nem véletlenül, a szankció súlyossága és a felderítés valószínűsége határozza meg. ${ }^{27}$ Ebből következően a bírság akkor optimális, ha nem csak az okozott kárt (benne a jogérvényesítés költségét), hanem a felderítés valószínủségét is kifejezi. ${ }^{28}$

${ }^{26} \mathrm{Az}$, hogy van EU-szabályozás, még egyáltalán nem jelenti, hogy nincsenek ipari katasztrófák. VERSLUIS, EstherVan Asselt, Marjolein-Fox, Tessa-Hommels, Anique: Calculable Risks? An Analysis of the European Seveso Regime. In: Goodwin, Morag-Koops, Beert-Jaag-Leenes, Ronald (eds.): Dimensions of Technology Regulation, Wolf Legal Publishers, 2010, 264.

${ }^{27}$ GAL, Michal: Harmful Remedies: Optimal Reformation of Anticompetitive Contracts. Cardozo Law Review, 2000/1, 91-132.

14028 SMUDA, Florian: Cartels and Fines, In: Whelan, Peter (ed.): Research Handbook on Cartels. Edward Elgar Publishing, 2021. 
Minél élénkebben lehet egy magatartási mintát korábbi beavatkozással társítani, annál nagyobb az elrettentő hatás a konkrét esetben. Ezért van szoros összefüggés a specifikus és generális elrettentés között. Minél láthatóbb a speciális prevenció (például bírságok, magatartásbeli vagy strukturális beavatkozások), annál nagyobb tehát a generális elrettentő hatás (ezt közvetett mechanizmusként is ismerjük). ${ }^{29}$ A modern viselkedéstudomány kutatásai is azt támasztják alá, hogy a bírságkiszabásról folytatott széleskörü kommunikáció növeli a tettenérés veszélyérzetét annak ellenére, hogy a valóságban a tettenérésre nincs nagy esély. ${ }^{30}$ Következésképpen fontos, hogy legyen hatékony kommunikáció a bírságkiszabásról. ${ }^{31}$ A bírság kiszabásának tényleges fenyegetése ugyanis eltántoríthatja a vállalkozásokat a versenyellenes magatartástól a jövőben.

A versenyjogi eszköztár tekintetében nem csak a bírságoknak és strukturális vagy magatartási korrekcióknak, hanem az engedékenységnek is van egy elrettentő funkciója. Az engedékenység a fogolydilemma helyzetet igyekszik erősíteni a kartell tagjai közötti belső bizalom aláásásával, azzal a megnövelt kockázattal, hogy valamely résztvevő bejelenti a jogsértést az engedékenységi program előnyeiből való részesedés érdekében. ${ }^{32}$

Az ex-post szabályozói beavatkozás lehet magatartási és strukturális is. Ahogyan fent is említettem, az ex-ante szabályozással ellentétben az ex-post beavatkozás keretei között végrehajtott magatartási vagy strukturális korrekciók múltbeli piaci magatartáson alapulnak. Az ilyen korrekcióknak szintén lehet prevenciós hatása. Alább azt mutatom be, hogy a bírságok korlátozott elrettentő hatását milyen módon tudja ellensúlyozni az ex-ante szabályozás bevezetéséből vagy az ex-post magatartási vagy strukturális korrekciós intézkedések alkalmazásából fakadó elrettentő hatás.

\section{A prevenció korlátai a versenyjogban}

Fentiek fényében a versenyjog akkor teremt közértéket, ha a fogyasztói jólétre káros piaci hatalmat megelőzi, kiküszöböli. Ebből a szempontból a versenyjog preventív hatásának felmérése során figyelembe kell venni azokat az eltérő módokat, ahogyan a piaci hatalom létrejöhet.

Először is vannak azok a piaci formációk, amelyek úgy hoznak létre piaci hatalmat, hogy együttmúködés révén mesterségesen felszámolják az egyébként létező versenyt a versenytársak között (például kartellek). Másodsorban vannak „természetes" piaci hatalmak, amelyek akkor jönnek létre, ha egyetlen vállalat hatékonyabban termel a piacon ${ }^{33}$ (lásd a hálózatos iparágak szereplőit), amely ettől még társadalmi

${ }^{29}$ BRoulík, Jan: Preventing Anticompetitive Conduct Directly and Indirectly: Accuracy versus Predictability. The Antitrust Bulletin, 2019/1, 118.

${ }^{30}$ DE MONCUIT, Godefroy: Relevance and Shortcomings of Behavioural Economics in Antitrust Deterrence. Journal of European Competition Law \& Practice, 2020/5-6, 230.

${ }^{31}$ De Moncuit: i. m., 232.

32 Spagnolo, Giancarlo: Optimal Leniency Programs. Working Paper, Fondazione Eni Enrico Mattei, 2000/42.

${ }^{33}$ VIscusi, W. Kip - HARRIngton, Joseph E. Jr.-Vernon, John M.: Economics of Regulation and Antitrust. Cambridge, Mass., MIT Press, 2005, 401. 
szinten káros, monopol árat fog alkalmazni. Harmadsorban vannak azok a piaci hatalmak, amelyek szintén versengő piaci körülmények között jönnek létre, jellemzően saját innovációjukra, szellemi tulajdonra és az ennek köszönhető jogi monopóliumra építve. Negyedrészt pedig piaci hatalmak létrejöhetnek állami beavatkozás eredményeként is, de ezzel kapcsolatban a piaci prevenció nem értelmezhető, ${ }^{34}$ ezért ezzel az esettel a továbbiakban nem foglalkozom.

A versenyjog preventív hatása és ebböl következően esetleges korlátai - eltérő módon ugyan, de - a fenti három esetben értelmezhetők, mert a hálózatos iparágak példája mutatott rá, hogy a technológiai fejlödés és az ennek köszönhető költségmegtakarítás még ezeket a természetes monopólium jellemezte piacokat is támadhatóvá teheti, ${ }^{35}$ ami versengő helyzetet és a versenyjog alkalmazhatóságát teremti meg. A nem versenyben létrejött természetes monopóliumok sem állnak fenn ezért tartósan, viszont a megjelenő verseny kialakulásának és megerősítésének támogatására a versenyjog nem elegendő. A tanulmány kontextusában fogalmazva: a versenyjog nem jelent elég visszatartó erőt, hogy a természetes monopóliumból a versenybe való átmenet ne szenvedjen sérelmet, miként ezt a távközlés esete mutatja. ${ }^{36}$ Ennek oka egyrészt, hogy a versenyjogot csak lassú és nehézkes eljárások során lehet alkalmazni; másrészt ezt tetézi, hogy a versenyteremtéshez szükséges feltételek kialakításához sok esetben (mint például az energetika és a távközlés esetében) komoly ágazati és müszaki szakismeret szükséges, amelynek a versenyhatóságok jellemzően nincsenek birtokában. A természetes monopóliumok lebontása és piacaik versenyzővé tétele (a hálózaton és a hálózatok között folyó verseny révén) versenyjogot meghaladó ex-ante szabályozást igényelnek. ${ }^{37}$

A versenyben létrejövő piaci hatalmak esetében is vannak olyan helyzetek, amelyek során a bírságok ex-post alkalmazása hatástalannak bizonyul, mert a károkozás megismétlődik. Amennyiben vannak visszatérő, versenyt érintő problémák egy piacon, úgy ez erős jelzés arra vonatkozóan, hogy a versenyügyi bírságok önmagukban nem bírnak elégséges visszatartó erővel. Az ex-post beavatkozással elérhető elrettentés ilyenkor nem képes hatékonyan visszatartani a jogsértéstől, és kikényszeríteni a jogkövető magatartást. Ilyen esetekben további preventív eszközöket is számításba kell venni, úgymint az ex-ante szabályozás vagy a strukturális beavatkozás (például feldarabolás).

A korábban már említett, digitális piacokról szóló jogszabályra (Digital Markets Act) irányuló javaslat (a továbbiakban: DMA-javaslat) ${ }^{38}$ indokolása is kifejezetten elismeri, hogy a versenyjogi érvényesítés utólag történik, és gyakran nagyon összetett

${ }^{34}$ Esetleg az EU állami versenyjog visszatartó hatását lehetne értékelni az EU-tagállamok monopóliumot létrehozó döntései kapcsán, de ez nem a vállalati versenyjogi szabályokra, hanem az azok védelmére alkotott alkotmányos versenyjogi szabályokra vezethető vissza.

35 VISCUSI-HARRINGTON-VERNON: i. m., 402.

${ }^{36}$ Erről részletesen lásd TóтH András: Az elektronikus hírközlés és média gazdasági szabályozásának alapjai és versenyjogi vonatkozásai. HVG-ORAC, Budapest, 2008.

37 TIROLE, Jean: Telecommunication and Competition. In: Buigues, Pierre A.-Rey, Patrick (eds.): The Economics of Antitrust and Regulation in Telecommunication. Edward Elgar Publishing, 2004.

14238 Javaslat AZ EURÓPAI PARLAMENT ÉS A TANÁCS RENDELETE a digitális ágazat vonatkozásában a megtámadható és méltányos piacokról (digitális piacokról szóló jogszabály). COM/2020/842 final. 
tények kiterjedt, eseti alapú vizsgálatát igényli. ${ }^{39} \mathrm{Az}$ Európai Unió Működéséről szóló Szerződés 102. cikkét csak lassú és nehézkes eljárások során lehet alkalmazni. Például a Bizottság 6 éves vizsgálat után kötelezte a $60 \%$-os piaci részesedésű Microsoft-ot, hogy tegye lehetővé a hozzáférést a versenytársai számára. ${ }^{40}$ Két évvel később, amikor a Bizottságnak büntetőbírsággal kellett arra kényszerítenie a Microsoft-ot, hogy teljesítse is a kötelezettségeit, a cég piaci részesedése már $74 \%$ volt. ${ }^{41}$ De nézzünk egy újabb keletű példát, a Google-ügyet, amely során - hét év vizsgálat után - szabott ki bírságot a Bizottság a vállalkozásra, mert előnyben részesítette saját ár-összehasonlító szolgáltatását. Ebben az ügyben pedig úgy tűnik, hogy a Google kötelezése a versenykorlátozó üzleti gyakorlat korrigálására a mai napig nem oldotta meg a versenytársak problémáit, mert azt nem sikerült jól célozni. ${ }^{42}$ Mindezek a példák azt támasztják alá, hogy jelentős vagy tartós piaci hatalmak esetében a versenyjogi ex-post beavatkozások visszatartó ereje csekély hatású lehet, miközben átmenetileg (az ex-ante szabályozás megszületéséig) az egyetlen szabályozói eszközt jelentik.

A bírságok elégtelen elrettentő hatása a verseny területén a következő tényezőkböl is fakadhat:

- az óriáscégeket nem rendíti meg az eröfölénnyel való visszaélés miatt rájuk kiszabott bírság, és nem tartanak a jó hírnevük sérelmétől sem; ${ }^{43}$

- a visszaesések magas aránya ${ }^{44}$ gyakran a jogsértő cégek optimizmusából fakad; nem tartják valószínünek, hogy ismételten tetten érik őket, ${ }^{45}$ illetve a vállalkozások túlértékelhetik az alacsony valószínűségét annak, hogy a kartelleket egyáltalán felderítik, ${ }^{46}$

- ha a kartellt és a visszaélést lehetővé tevő piaci struktúrák változatlanul maradnak, akkor a bírságok fenntartható módon nem jelentenek hatékony visszatartó erőt;47

- a versenyellenes magatartás nem jár olyan társadalmi elítéléssel, mint a fehér galléros bűnözés vagy az adókijátszás; ${ }^{48}$

${ }^{39}$ DMA-javaslat 5. preambulum-bekezdés.

${ }^{40}$ Case COMP/C-3/37.792 Microsoft, Commission Decision C(2005) 4420 final.

${ }^{41}$ Commission Decision C(2008) 764 final.

${ }^{42}$ Foo, Yun Chee-Waldersee, Victoria: EU's Vestager Says Google's Antitrust Proposal Not Helping Shopping Rivals. Reuters, 2019. https://www.reuters.com/article/us-eu-alphabet-antitrust-idUSKBN1XH2I8 (2021. 03. 15.).

43 TIROLE: i. m.

${ }^{44}$ BAREnNes, Marc-Wolf Stephen G.: Cartel Recidivism in the Mirror of EU Case Law. Journal of European Competition Law \& Practice, 2011, 423.; WILS, Wouter P. J.: Recidivism in EU Antitrust Enforcement: A Legal and Economic Analysis. World Competition, 2012/1.

${ }^{45}$ DE MONCUIT: i. m., 233.

${ }^{46}$ Combe, Emmanuel-Monnier Constance-Legal Renaud: Cartels: The Probability of Getting Caught in the European Union. Working Paper PRISM-Sorbonne, Paris, 2008. A szerzök szerint az éves valószínüsége a tettenérésnek 12,9\% és 13,3\% között van. The Deterrent Effect of Competition Enforcement by the OFT: A Report Prepared for the OFT by Deloitte. London, 2007. (https://webarchive.nationalarchives.gov.uk/ukgwa/20140402141250/http:/www.oft.gov.uk/shared_oft/reports/Evaluating-OFTs-work/oft962.pdf) A felmérés 1 az 5-höz arányt (tehát ötszörös elrettentő hatást) mutatott ki a fúzióellenőrzés és a kartellel kapcsolatos jogérvényesítés tekintetében az Egyesült Királyságban a 2000-2006 közötti periódusra.

47 Thompson, John S-Kaserman, David L: After the Fall: Stock Price Movements and the Deterrence Effect of Antitrust Enforcement. Review of Industrial Organization, 2001/3, 329-334.

${ }^{48}$ SokoL, Daniel: Cartels, Corporate Compliance, and What Practitioners Really think About Enforcement. Antitrust Law Journal, 2012/1, 217-218. 
- előfordul, hogy a tulajdonosok nem várnak el olyan cégkultúrát, amely megköveteli a jognak való megfelelést, ${ }^{49}$ ráadásul, ha a cégek vezetői magas kockázati toleranciaszinttel bírnak, nagy valószínüséggel fognak jogsértő üzleti stratégiát választani, ${ }^{50}$ hiszen a versenytársak piacról kiszorítása, piaci hatalom megszerzése több profitot eredményez. ${ }^{51}$

\section{A prevenció maximális szintjének elérése a versenyjogban}

Ahogyan korábban említettem, a szociális szabályozás területén kidolgozott, problémamegoldás-orientált megközelítés átültethető lehet a versenyjogba akként, hogy valamennyi rendelkezésre álló eszközt következetesen és átfogóan használ a versenyhatóság a versenyben létrejött piaci hatalom megelőzésére, illetve felszámolására.

Amíg a bírságok és kötelezettségek ex-post alkalmazása széles körben elterjedt, addig kevés szó esik az ex-ante szabályozásra való átváltás és a strukturális beavatkozások (például feldarabolások) illetve az azokkal való fenyegetés alkalmazásával járó preventív hatásról. Vannak, akik a prevenció alapvető eszközének a bírságkiszabást tekintik, ${ }^{52}$ én azonban nem osztom ezt a nézetet. $A$ bírságolás ugyanis egy átfogó megelőzésre szolgáló eszköztár része. Ennek az eszközkészletnek az elemeit következetesen kell használni annak érdekében, hogy maximalizáljuk a megelőzésből fakadó társadalmi hasznot és ezzel több közértékét hozzunk létre. A közértéket jelentő prevenció ezen magasabb foka különösen fontos, amikor a piacok egyre inkább koncentrálódnak. ${ }^{53}$

Annak érdekében, hogy elérjük a maximális preventív hatást (és ezzel több közértéket teremtsünk), minden megelőző eszköznek hatékonyan kell működnie. Ehhez minden megelőző eszköz következetes és átfogó használata szükséges:

- látható, speciális preventív intézkedések az általános elrettentés megfelelő müködése érdekében;

- nem csak bírságokat, hanem magatartási és strukturális korrekciókat is magukba foglaló ex-post beavatkozások, mint az EU energetikai piacai esetében;

- átváltás az ex-post elrettentésre épülő megközelítésröl az ex-ante szabályozás felé, amennyiben a károkozás az ex-post elrettentés ellenére ismétlődik (akár a

${ }^{49}$ DE Moncuit: i. m., 231.; Combe, Emmanuel-Monnier-Schlumberger, Constance: Why Managers Engage in Price Fixing? An Analytical Framework. World Competition Law and Economics Review, 2020/1, 35-60.

${ }^{50}$ Bernile, Gennaro-Bhagwat, Vineet-Rau, Raghavendra P.: What Doesn't Kill YouWill Only Make You More Risk-Loving: Early-Life Disasters and CEO Behavior. The Journal of The American Finance Association, 2017/1, 167-206. (https://doi.org/10.1111/jofi.12432)

51 DE MONCUIT: i. m., 236.

52 Hüschelrath, Kai-Weigand, Jürgen: Fighting Hard Core Cartels. ZEW Discussion Papers, 10-084, 2010, 24.; BLOCK, Michael Kent-NoLD, Frederick Carl: The Deterrent Effect of Antitrust Enforcement. Journal of Political Economy, 1981/3, 429-445.; VELJANOVsKI, Cento: Cartel Fines in Europe. World Competition, 2007/1, 65-86.; lásd HUIZING: i. m.

53 StiglitZ: i. m. 
versenyhatóságokat fel lehet ruházni ezekkel az ex-ante szabályozói eszközökkel, mint az alábbiakban említett német jogszabály-tervezet esetén);

- az ex-post elrettentés kiterjesztése, bírságon kívüli következmények (személyes felelősség, magánjogi jogérvényesítés) irányába.

\subsection{Az ex-post beavatkozásról az ex-ante szabályozásra való átváltás}

Az ex-post elrettentés csekély hatékonysága esetében egyfelől megoldást az ex-ante szabályozás, vagyis az elvárt magatartások konkrét előzetes meghatározása jelentheti, amely egyúttal a jogkövetés kikényszerítésének hatékonyságát is fokozza. Erre szolgál példaként a digitális gazdaság, amelynek versenyproblémái kapcsán maguk a versenyhatóságok (ide értve az Európai Bizottságot, amelynek digitális korszakért felelős ügyvezető alelnöke egyben az EU versenyügyi biztosa is) azok, akik a technológiai óriások szabályozás alá vonását sürgetik az EU-ban, legtöbbször úgy, hogy az új hatáskörök gyakorlására magukat ajánlják. A BENELUX államok versenyhatóságainak közös nyilatkozata ${ }^{54}$ és a francia versenyhatóság javaslata ${ }^{5}$ is a versenyhatóságok digitális óriásokkal szembeni megerősítése mellett érvel. A 2021-ben elfogadott német szabályozás pedig már fel is jogosította a német versenyhatóságot a digitális kapuőrökkel szembeni fellépésre. ${ }^{56}$

Az Australian Competition and Consumer Commission ${ }^{57}$ a brit versenyhatósághoz hasonlóan ${ }^{58}$ a versenyhatóságon belüli dedikált szervezeti egység létrehozását javasolta, a versenyjogot kiegészítő további eszközök megteremtése mellett. Miközben tehát a versenyhatóságokat bírálatok érték amiatt, hogy a technológiai óriások a szemük láttára és némely esetben az asszisztálásuk mellett nőttek nagyra, addig az EU-ban a versenyhatóságok a technológiai óriások megregulázásának zászlóvivői, és úgy tünik az új hatáskörök élvezői is lesznek. Mindenképpen figyelemre méltó fejlemény, hogy az EU-ban a versenyhatóságok ilyen értelemben megerősödve kerülnek ki a kritikákból.

Az OECD szerint ugyanakkor a piaci hatalmak ex-ante szabályozás alá vonása felvetheti az ex-post beavatkozás hatékonyságának kérdését. ${ }^{59}$ Jelen tanulmányom

${ }^{54}$ Joint memorandum on challenges faced by competition authorities in a digital world. Belgian Competition Authority, Dutch Authority for Consumers \& Markets, and Luxembourg Conseil de la Concurrence, 2019. https:// www.belgiancompetition.be/en/about-us/publications/joint-memorandum-belgian-dutch-andluxembourgcompetition-authorities (2021. 03. 15.).

${ }_{55}^{5}$ L'Autorité publie sa contribution au débat sur la politique de concurrence face aux enjeux posés par l'économie numérique. Autorité de la concurrence, 2020. február 21. www.autoritedelaconcurrence.fr/fr/communiques-de-presse/lautorite-publie-sa-contribution-au-debat-sur-la-politique-de-concurrence (2021. 03. 15.).

${ }^{56}$ Amendment of the German Act against Restraints of Competition, 19. 01. 2021. https://www.bundeskartellamt.de/SharedDocs/Meldung/EN/Pressemitteilungen/2021/19_01_2021_GWB\%20Novelle.html (2021. 03. 15.).

${ }_{57}$ Digital platforms inquiry. Australian Competition and Consumer Commission, 2019. https://www.accc.gov.au/ focus-areas/inquiries-ongoing/digital-platforms-inquiry (2021. 06. 10.)

${ }^{58}$ Online Platforms and Digital Advertising Market Study Final Report. Competition and Markets Authority, 1 July 2020.

59 Abuse of Dominance in Digital Markets, OECD, 2020. www.oecd.org/competition/globalforum/abuse-of-dominance-in-digital-markets.htm (2021. 03. 15.). 
azonban éppen arra kívánja felhívni a figyelmet, hogy ez az átváltás az ex-post beavatkozás és ex-ante szabályozás között nemhogy nem hátrány, de kifejezetten prevenciós célokat szolgálhat, ezért stratégiailag volna indokolt használni.

A prevenció magasabb szintű múködését jelentheti tehát, ha az ex-post elrettentés hatástalansága esetén a versenyhatóság stratégiailag él az ex-ante szabályozás alá vonási javaslattal. Ugyanakkor a versenyhatóságoknak tudatosabban és következetesebben kellene követniük ezt a gyakorlatot, és nem csak a digitális piacok tekintetében. Minden olyan szabályozási javaslat, amely elszakad az érintett piac meghatározásától, ${ }^{60}$ vagy amely az erőfölénnyel való visszaélés tilalmát olyan vállalkozásokra is kiterjeszti, amelyek nem érik el ezt a szintet, lényegében új ex-ante szabályozás felé mutat. ${ }^{61}$ Továbbá az ex-post elrettentés eredménytelensége által motivált ex-ante szabályozás müködtethető a versenyhatóság révén úgy, mint ahogyan a német ${ }^{62}$ és belga ${ }^{63}$ digitális piaci szabályozás tervezet javasolta.

\subsection{Strukturális beavatkozások}

A strukturális (a piac szerkezetébe, a tulajdonviszonyokba való) versenyhatósági beavatkozások nem ismeretlenek sem az EU-ban, sem pedig az USA-ban. Már önmagában a feldarabolási fenyegetettség visszatartó erővel bírhat, ezért szükséges a szabályozás alá vonási javaslat stratégiai kezelése. Például, amikor a Microsoft az USA-ban feldarabolási fenyegetéssel szembesült, akkor egyes vélemények szerint önkorlátozásba menekült. ${ }^{64}$ Ennek köszönhetően a Microsoft internetes böngészője eljelentéktelenedett, ahogyan azok is, akik annak a haszonélvezői voltak. Mára a piacvezető internetes böngésző a Google Chrome.

Míg az USA-ban széles körü történelmi gyakorlat áll rendelkezésre a vállalati feldarabolás terén, ${ }^{65}$ addig erre az EU-ban inkább csak az infrastruktúrális szektorban

${ }^{60}$ Schweitzer, Heike-Haucap, Justus-Kerber, Wolfgang-WelkeR, Robert: Modernising the Law on Abuse of Market Power, 2018. (https://dx.doi.org/10.2139/ssrn.3250742).

61 Wiggers, Marc-Verstraeten, Thomas-Struijlaart, Robin: New Rules Prohibiting the Abuse of Economic Dependence Entered into Force in Belgium on 22 August 2020 - What does this mean for the digital sector? Competition Law Blog, 10 September 2020. http://competitionlawblog.kluwercompetitionlaw.com/2020/09/10/new-rules-prohibiting-the-abuse-of-economic-dependence-entered-into-force-inbelgium-on-22-august-2020-what-does-this-mean-for-the-digital-sector/ (2021. 03. 15.); Entwurf eines Gesetzes zur Änderung des Gesetzes gegen Wettbewerbsbeschränkungen für ein fokussiertes, proaktives und digitales Wettbewerbsrecht 4.0 und anderer wettbewerbsrechtlicher Bestimmungen (GWB-Digitalisierungsgesetz). BMWi, Stand: 07.09.2020. https://www.bmwi.de/Redaktion/DE/Downloads/Gesetz/ gesetzentwurf-gwb-digitalisierungsgesetz.pdf?__blob=publicationFile\& (2021. 03. 15.); Unlocking Digital Competition. Report of the Digital Competition Expert Panel, 2019, 84. https://assets.publishing.service. gov.uk/government/uploads/system/uploads/attachment_data/file/785547/unlocking_digital_competition_furman_review_web.pdf (2021.03.15.).

62 GWB-Digitalisierungsgesetz i. m.

${ }^{63}$ Wiggers-Verstraeten-Struijlaart: i. m.

64 Tepper-Hearn: i. m., 94.; Lamoreaux, Naomi, R.: The Problem of Bigness: From Standard Oil to Google. Journal of Economic Perspectives, 2019/3, 58.

65 Összességében több tucat ilyen eset volt a 20. században. SulLIVAN, E. Thomas: The Jurisprudence of Antitrust Divestiture: The Path Less Traveled. Minnesota Law Review, 2002, 1178. 
(jellemzően az energetikában ${ }^{66}$ ) van példa. A brit szabályozás ${ }^{67}$ is versenyjogon kívül teszi lehetővé, a piaci verseny alapjainak megteremtése érdekében, piacvizsgálat keretei között, igaz versenyhatósági hatáskörbe utaltan. Ezt a brit szabályozást alapul véve ${ }^{68}$ - szemben a szektorfüggetlen brit szabályozástól - a Bizottság DMAjavaslata csak a digitális piacokban teremtené meg a feldarabolás lehetőségét.

Az USA-ban így nem lehet véletlen, hogy a technológiai óriásokkal szemben megfogalmazott kifogások hatására a versenyhatóságok feldarabolási kereseteket adtak be. 2020. október 20-án ugyanis az USA igazságügyi minisztere és még 11 republikánus állam föügyésze pert indított a Sherman Act 2. § alapján a Google ellen, és kérték a bíróságtól annak feldarabolását. ${ }^{69}$ Ezt követte 2020. december 9-én a szövetségi kereskedelmi bizottság (FTC), amely beperelte a Facebookot, a 46 állam legföbb ügyészével együttmüködve. Az FTC a szövetségi bíróságon olyan döntést kért, amely többek között az Instagram és a WhatsApp leválasztását teremtené meg. ${ }^{70}$ Ezen kereset tükrözi azt az amerikai irodalmi álláspontot, amely szerint azon múltbeli fúziókat, amelyek hozzájárultak a technológiai óriások megerősödéséhez, utóbb felül kellene vizsgálni. ${ }^{71}$

https://scholarship.law.umn.edu/mlr/1178 (2021. 03. 15.) Ezek közül talán a legnevezetesebbek a következők. 1911: a Standard Oil; 1945: az Alcoa; 1967: a United Shoe Machinery feldarabolása; 1973-ban az FTC nyolc olajvállalatot (Exxon, Shell, Mobil, Texaco, Socal, Gulf, Amocom és Arco) darabolt fel azáltal, hogy kötelezte őket finomítói kapacitásuk 40-60\%-ának eladására; 1982: az AT\&T feldarabolása.

${ }^{66}$ 2013-ban a Bizottság elfogadta a CEZ kötelezettségvállalását annak kapcsán, hogy elidegeníti a termelőeszközei egy részét (erőműveket; 800-1.000 MW) egy megfelelő vásárló (versenytárs) számára a Cseh Köztársaságban. [Case AT.39727 - CEZ; Commission Decision C(2013) 1997]. 2009-ben az RWE AG egy, a gázszállító piacon erőfölényes vállalkozás kihasználva a németországi hálózata nyújtotta lehetőségeket, elindította a német gázszállító vállalatának divesztícióját. [Case COMP/39402 - RWE Gas Foreclosure; Commission Decision C(2009) 133/08] 2008-ban az E.ON elindította a termelőkapacitásai egyötödének divesztícióját, valamint a teljes nagyfeszültségủ hálózati rendszer leválasztását a németországi cég ellenőrzése alatt tartott elosztási hálózatról. [Case COMP/39388 - German Electricity Wholesale Market; Commission Decision C(2009) 36/08] 2010-ben az ENI kötelezettséget vállalt arra, hogy eladja egy megfelelő vásárló részére Olaszországban a nemzetközi gázszállító vezetékeit, amelyek Oroszországból és ÉszakEurópából hoznak be gázt [Case COMP/39315 - ENI (2010)].

${ }^{67}$ Enterprise Act 2002, https://www.legislation.gov.uk/ukpga/2002/40/schedule/8 (2021. 03. 15.).

${ }^{68}$ Whish, Richard: New Competition Tool: Legal Comparative Study of Existing Competition Tools Aimed at Addressing Structural Competition Problems with a Particular Focus on the UK's Market Investigation Tool (expert study). Publications Office of the European Union, Luxembourg, 2020 https://ec.europa.eu/competition/consultations/2020_new_comp_tool/kd0420573enn.pdf (2021. 03. 15.).

69 Department Files Complaint Against Google to Restore Competition in Search and Search Advertising Markets, 20 October 2020. https://www.justice.gov/opa/pr/justice-department-sues-monopolist-google-violatingantitrust-laws (2021. 03. 15.).

${ }^{70}$ FTC Sues Facebook for Illegal Monopolization. Federal Trade Commission, 9 December 2020. https://www. ftc.gov/news-events/press-releases/2020/12/ftc-sues-facebook-illegal-monopolization (2021. 03. 15.)

71 TEPPER-HEARN: i. m. A Facebook ellen megfogalmazott vádban az FTC azt állította, hogy a vállalkozás a monopolhelyzetét érő fenyegetések elhárítására szisztematikus stratégiát alkalmazott, amikor a WhatsAppot és az akkor feljövő riválisát, az Instagramot megszerezte. 


\subsection{A piaci szereplők megregulázása és a piaci verseny megnyerhetöségének ideája}

Míg az USA-ban a versenyhatóságok feldarabolási kereseteket adtak be, a politikusok európai stílusú szabályozási javaslatokat fogalmaztak meg. ${ }^{72}$ Közben a politikusok az Európai Unióban is felvetik az amerikai technológiai óriások feldarabolását ${ }^{73}$ és versenyhatóságok sürgetik a szabályozási megoldást. Kérdés, hogy a versenyjogi prevenció eszköztárának strukturális beavatkozásokkal és ex-ante szabályozási kezdeményezésekkel való felváltása miként hat ki a piacgazdaság legfőbb motivációja, a verseny megnyerhetőségének ideájára. Ez ugyanis természetes következménye a versenynek, aminek legfőbb ígérete, hogy megnyerhető. A piaci szereplők számára ez a piacgazdaság által kínált legfőbb motivációk egyike, hogy a piaci versenyt innovációval megnyerve piaci hatalomra tehetnek szert, miként az a digitális óriások esetében is jól látszik. ${ }^{74}$

Ezzel kapcsolatban egyrészről el lehet mondani, hogy a feldarabolások több esetben (így a Standard Oil, az American Tobacco és az Alcoa esetében) inkább pozitívan érintették a részvényeseket, ${ }^{75}$ miközben a károsodásra vezető körülményeket megszüntették. Az AT\&T sem a feldarabolás, hanem az azt követő liberalizációnak köszönhetöen veszített a bevételeiből.

Másfelöl a szabályozás alá vonás nem érinti a piaci verseny megnyerhetőségének ideáját, amikor természetes monopóliumok versenynek való alávetésére kerül sor, hiszen azok eleve nem is versenyben jöttek létre. Ma már ezért az sem feltétlenül igaz, amit Milton Friedman figyelt meg, miszerint ha a monopóliumok megérték, hogy végül szabályozási korlátok közé kerüljenek, akkor a szabályozás tartósan konzerválta őket és ezért a szabályozás haszonélvezői lettek. ${ }^{76}$ Friedman ugyanis ezt a megállapítását abban a korban tette, amikor a természetes monopóliumokat tartós, versenyt helyettesítő szabályozás alá vonták. Az 1980-as években elindult liberalizáció azonban létrehozta a versenyt teremtő piacszabályozások generációját, amelyek célja ezen monopolpozíciók lebontása és az ilyen piacok megnyitása a versenynek.

Harmadrészt, a kérdés élesebben merül fel a technológiai óriások megregulázása kapcsán, hiszen ezek nemcsak versenyben jöttek létre, de piaci hatalmukat szellemi innovációnak köszönhetik. Ez a különbség pedig mindenképpen jelentős. A Schumpeter-i versenyelmélet szerint a szellemi tulajdont létrehozó beruházás jutalma a monopolhelyzet, amely biztosítja a szellemi tulajdon létrehozásába való be-

\footnotetext{
${ }^{72}$ Mattioli, Dana-Tracy, Ryan: House Bills Seek to Break Up Amazon and Other Big Tech Companies. The Wall Street Journal, updated 11 June, 2021. https://www.wsj.com/articles/amazon-other-tech-giantscould-be-forced-to-shed-assets-under-house-bill-11623423248 (2021. 06. 15.).

${ }^{73}$ Robertson: i. m.; France and Netherlands Join Forces to Back EU Move Against Tech Giants. Financial Times, 2020. 10. 24. https://www.ft.com/content/4a9ed79e-c8c8-4b47-8055-1cd029541c32 (2021. 03. 15.).

${ }^{74}$ WAKED, Diana I.: Antitrust as Public Interest Law: Redistribution, Equity and Social Justice. The Antitrust Bulletin, 2020/1, 98. (https://doi.org/10.1177\%2F0003603X19898624)

${ }^{75}$ Armentano, Dominick T.: The Microsoft Case: Divestiture Won't Help Consumers. Independent Institute, 1 April 2000. https://www.independent.org/news/article.asp? $i d=170$ (2021. 03. 15.).

${ }^{76}$ Tepper-Hearn: i. m., 179.
} 
fektetés megtérülését. ${ }^{77}$ Ráadásul a szellemi tulajdon alapú versennyel (technológiai haladással) jellemzett piacokon az ilyen monopóliumok nem állnak fenn tartósan, szemben a természetes hálózat/infrastruktúra alapú piacokon. ${ }^{78}$ Ezért ilyen esetben a szellemi tulajdon elismerése és a befektetések ösztönzésének fenntartása miatt másfajta, óvatosabb szabályozási megközelítésre van szükség. ${ }^{79}$

Az innováció elismerésének kézenfekvő szabályozási módja lehet, ha a szabályozás a piac támadhatóságán keresztül közvetve segíti a verseny élénkülését, mint a DMA-javaslat, amely a felhasználók és üzleti partnerek számára tenné átjárhatóbbá és tisztességesebbé a platformok jelentette üzleti és felhasználói környezetet. Ez egyfajta „tisztességességi” piac-szabályozás. Különbséget kell tenni a folyamat tisztessége, amelyet eljárási igazságosságnak neveznek, és az eredmények (kimenet) igazságossága között. ${ }^{80}$ Motta ${ }^{81}$ szerint a folyamat tisztességességre (a tisztességes eljárásra, elbánásra) ${ }^{82}$ építő szabályozása jobban összehangolható a piaci verseny hatékonysági és így befektetést ösztönző céljaival, kevésbé ássa azokat alá. ${ }^{83}$ Nem véletlen, hogy a DMA-javaslat szabályozási koncepciója is ezen alapul, és az annak kiinduló pontját képező, úgynevezett P2B rendelet ${ }^{84}$ is már az üzletfelekkel való bánásmód átláthatóságára helyezte a hangsúlyt.

A negyedik esetet a szellemi tulajdonhoz való hozzáférés szabályozás általi biztosítása jelenti. Az Európai Bizottság 2020 elején kiadott adatstratégiájában jelezte, hogy a piaci szereplök közti (B2B) adatmegosztást egy 2021-re tervezett adattörvényben elsősorban önkéntes alapon ösztönözné, de bizonyos szektorok esetében akár kötelezővé is tenné, FRAND (fair, reasonable, and non-discriminatory) alapon, ha a versenyjog nem lenne elégséges. ${ }^{85}$ Létezik már ilyen szektorális szabályozási előírás kötelező adatmegosztásra, például az autójavítás körében használatos

77 SHELANSKI, Howard A.-SIDAK, J. Gregory: Antitrust Divestiture in Network Industries. The University of Chicago Law Review, 2001/1, 5.

${ }^{78}$ SHELANSKI-SIDAK: i. m., 6.

${ }^{79}$ Lásd: Dutch Vision on Data Sharing between Businesses. Ministry of Economic Affairs and Climate Policy (Report), 2019. www.government.nl/documents/reports/2019/02/01/dutch-vision-on-data-sharing-betweenbusinesses (2021. 03. 15.).

${ }^{80}$ Konow, James: Which is the Fairest One of All? A Positive Analysis of Justice Theories. Journal of Economic Literature, 2003/4, 1188-1239.; OECD: Trust and Public Policy: How Better Governance Can Help Rebuild Public Trust, 2017, 68.

${ }^{81}$ MоттA, Massimo: Versenypolitika - Elmélet és gyakorlat. Gazdasági Versenyhivatal Versenykultúra Központja, 2007, 27.

82 BIGgar, Darryl: Fairness in Public-utility Regulation: A Theory. Agenda - A Journal of Policy Analysis and Reform, 2010/1.

${ }^{83}$ Platforms at the Gate? Initial Reactions to the Commission's Digital Consultations. Oxera, 18 June 2020. https://www.oxera.com/insights/agenda/articles/platforms-at-the-gate-initial-reactions-to-the-commissionsdigital-consultations/ (2021. 03. 15.).

${ }^{84}$ Az Európai Parlament és a Tanács (EU) 2019/790 irányelve (2019. április 17.) a digitális egységes piacon a szerzői és szomszédos jogokról, valamint a 96/9/EK és a 2001/29/EK irányelv módosításáról. HL L 130, 2019.5.17., 92-125.

${ }^{85}$ A Bizottság közleménye az Európai Parlamentnek, a Tanácsnak, az Európai Gazdasági és Szociális Bizottságnak és a Régiók Bizottságának - Európai adatstratégia. COM/2020/66 final, 16. 
egyes információk megosztásáról ${ }^{86}$ vagy a pénzügyi szektorban. ${ }^{87}$ Ezt az eszközt azonban éppen az innovációs ösztönzés (a piaci verseny megnyerhetőségének ideája) miatt körültekintően kell használni, az érintett szektor sajátosságai és az adatok jelentősége figyelembe vételével. Kérdés, hogy a technológiai óriások szolgáltatásai mögött van-e olyan szellemi tulajdoni alapanyag, amelyhez hozzáférve a versenytársak a vertikum alsóbb rétegeiben versenyző szolgáltatást tudnának kínálni (mint például az autógyártók diagnosztikai szoftverei esetében a független javítómühelyek). Ellenkező esetben felmerül, hogy nem ellentétes-e a közérdekkel, hogy ilyen mértékű adat halmozódik fel magánpiaci szereplők kezében, amire figyelemmel inkább az üzleti modell szabályozási megbontása lehet indokolt. ${ }^{88} \mathrm{~A}$ versenytársak hozzáférésének biztosítása ugyanis ez esetben olyan piacon élénkíti a versenyt, amelyből valójában társadalmi szinten több kár származik (figyelemelterelés, adatvesztések), mint haszon (ingyenes on-line szolgáltatások).

\subsection{Az ex-post elrettentés kiterjesztése}

Bár vannak elöremutató tanulmányok abban a körben, hogy a ténylegesen kiszabott kartellbírságok mennyiben maradnak el az optimálisan elvárttól, ${ }^{89}$ meg kell jegyezni, hogy további tartalékok vannak az ex-post beavatkozások elrettentő hatásának kiterjesztésében. Egy, az Európai Unió részére készült tanulmány kifejezetten a magánjogi jogérvényesítést és személyi szankciók alkalmazását nevesíti olyan eszközként, amelyek révén az ex-post elrettentő hatás tovább lenne fokozható. ${ }^{90}$ A Competition and Markets Authority (CMA) is amellett érvel, hogy a személyes szankciók alkalmazása (ideértve az igazgatók diszkvalifikálását) tovább fokozhatná a jogérvényesítés elrettentő hatását. ${ }^{91}$ Érdemes fontolóra venni a CMA azon javaslatát is, hogy a könyvvizsgálók, amennyiben munkájuk során olyan gyakorlatokat azonosítanak, amelyek növelik a versenyjogi kockázatokat, készítsenek erről jelentést a vállalat vezetése számára. ${ }^{92}$ Egy USA-ban készült felmérés szerint is a magánjogi

${ }^{86}$ Az Európai Parlament és a Tanács 715/2007/EK rendelete (2007. június 20.) a könnyű személygépjárművek és haszongépjárművek (Euro 5 és Euro 6) kibocsátás tekintetében történő típusjóváhagyásáról és a jármüjavítási és karbantartási információk elérhetőségéről. HL L 171, 2007.6.29., 1-16.

${ }^{87}$ Az Európai Parlament és a Tanács (EU) 2015/2366 irányelve (2015. november 25.) a belső piaci pénzforgalmi szolgáltatásokról és a 2002/65/EK, a 2009/110/EK és a 2013/36/EU irányelv és a 1093/2010/EU rendelet módosításáról, valamint a 2007/64/EK irányelv hatályon kívül helyezéséröl. HL L 337, 2015.12.23., 35-127.

${ }^{88}$ Erröl lásd Tóth András: Az adatmonopóliumok tündöklése és letörése In: Szabó Endre Győző (szerk.): Az Infotörvénytöl a GDPR-ig. Ludovika Egyetemi Kiadó, 2021, 168.

${ }^{89}$ Lásd SMUDA már hivatkozott optimális bírságról szóló tanulmányát.

${ }^{90}$ Feinberg Robert M.: The Enforcement and Effects of European Competition Policy: Results of a Survey of Legal Opinion. Journal of Common Market Studies, 1985/4, 373-384.; Resolution, International Ligue of Competition Law, Budapest 2018. https://www.ligue.org/en/members-2/intranet/budapest-congress-2018-reports (2021. 06. 10.).

${ }^{91}$ Letter from Andrew Tyrie to the Secretary of State for Business, Energy and Industrial Strategy, 21 February 2019, 23. https://www.gov.uk/government/publications/letter-from-andrew-tyrie-to-the-secretary-of-state-forbusiness-energy-and-industrial-strategy (2021. 03. 15.)

92 Letter from Andrew Tyrie....: i. m. 
jogérvényesítés úgy tűnik, hogy nagyobb szerepet játszik az elrettentő hatás kifejtésében, mint a hatósági jogérvényesítés. ${ }^{93}$

Az ex-post elrettentés hatásfoka tovább javítható a jogalkalmazási közleményekkel és a döntések még világosabb indokolásával. Az egyébként is komplex versenyjogi esetek bonyolult indokolásai ugyanis nem segítik elő a jogkövetést. ${ }^{94}$ Broulík szerint ezért van feszültség a speciális jogérvényesítés (ahol az akkurátusságnak van jelentősége) és az általános elrettentés között (amely esetben az elöreláthatóságnak van a legnagyobb jelentősége). ${ }^{95}$ Következésképpen, a versenyhatósági döntések felülvizsgálata során a bíróságoknak számba kell venniük, hogy az általuk elvárt indokolások milyen hatást gyakorolnak az érthetőségre és ezáltal a kiszámíthatóságra, végső soron pedig az általános elrettentésre. ${ }^{96}$

\section{5. Összegzés}

A versenyhatóságok (mint védelmi típusú állami szervek) célja közérték-teremtés. A védelmi típusú hatóságok esetében ez abban mérhető, hogy a károk megelőzése vagy felszámolása által a hatóságok mennyire járulnak hozzá a társadalmi problémák megoldásához. A versenyhatóságok a közértéket úgy teremtik, ha biztosítják a versengő piaci környezetet a piaci erő korlátozásával és a belépési akadályok eltávolításával. Ebben az értelemben kell a károk megelőzését is vizsgálni. A Sparrow által a szociális szabályozásra kidolgozott problémamegoldó mechanizmus a versenyjogba is átültethető annak érdekében, hogy elejét vegyük a versennyel kapcsolatos problémák ismétlődésének egy adott iparágban. Amellett érvelek, hogy a károk megelőzését kellene a versenyhatóságok működésének középpontjába helyezni. A megelőzés közértéke különösen fontos, amikor a piacok koncentrálódását figyelhetjük meg (lásd digitális gazdaság). Annak érdekében, hogy a versenyhatóságok a maximális preventív hatást elérjék (többlet közértékként), minden megelőzésre szolgáló eszközt hatékonyan kell müködtetni:

- látható speciális preventív intézkedésekre van szükség az általános elrettentés megfelelő müködése érdekében;

- nem csak a bírságolásra kell ügyelni, hanem magatartási és strukturális korrekciókat is alkalmazni kell;

- élni kell az ex-post elrettentésre épülő megközelítésről az ex-ante szabályozásra való átváltással, amennyiben az ex-post elrettentés ellenére a károkozás ismétlődik (akár a versenyhatóságokat is fel lehet ruházni az így kialakuló ex-ante szabályozói eszközökkel)

- erősíteni kell az ex-post elrettentő hatást a vállalati megfelelési környezet támogatásával, adott esetben személyi szankciók alkalmazásának bevezetésével.

\footnotetext{
${ }^{93}$ BeCKensteIn, Alan R.-Gabel, Landis H.: Antitrust Compliance - Results of a Survey of Legal Opinion. Antitrust Law Journal, 1982/3, 459-516.

${ }^{94}$ HaWk, Barry E.-DenaEIJER, Nathalie: The Development of Articles 81 and 82: Legal Certainty. In: Ehlermann, Claus Dieter - Atanasiu, Isabela (eds.): European Competition Law Annual 2000 - The Modernisation of EC Antitrust Policy. Hart Publishing, 2001. (http://dx.doi.org/10.5040/9781472559098)

${ }^{95}$ BRoulík: i. m., 125.

${ }^{96}$ BRoulík: i. m., 126.
} 
Érdekes fejlemény a digitális piacok esetében, hogy míg az USA-ban a versenyhatóságok feldarabolási kereseteket adtak be, a politikusok pedig európai stílusú szabályozási javaslatokat fogalmaztak meg, ezzel szemben az EU-ban a politikusok követelik a technológiai óriások feldarabolását, míg a versenyhatóságok azok, akik kezdeményezik a szabályozás alá vonásukat. A maximális versenyjogi preventív hatás érdekében a digitális piaci tapasztalatok ezzel éppen azt mutatják, hogy a versenyhatóságok mindkettőt stratégiailag alkalmazhatják és kombinálhatják. Bár pont a digitális piacok esetében ez hatással lehet a piaci verseny megnyerhetőségének ideájára, amelyet az ex-ante szabályozás kialakítása során mindenképpen figyelembe kell venni, de ez már nem versenyjogi, hanem piacszabályozási kérdés. 